\title{
The Extent of Applying Citizenship Values Among Jordan Universities Students
}

\author{
Khawla Izzat Al-Qadoumi ${ }^{1}$ \\ ${ }^{1}$ Faculty of Education Science, Irbid National University \\ Correspondence: Khawla Izzat Al-Qadoumi.
}

Received: October 20, 2020

Accepted: January 29, $2021 \quad$ Online Published: January 31, 2021

doi:10.5539/ass.v17n2p99

URL: https://doi.org/10.5539/ass.v17n2p99

\begin{abstract}
The study aimed at recognizing the degree of the teaching staff members in Irbid National University employment of citizenship values in teaching from the point of view of students, and also specify if there are differences with statistical significance ascribed to the variables of the study, they are: sex (male \& female) and type of the faculty (human and scientific). To achieve the study's objectives, both researchers applied the descriptive-analytical method, employing a questionnaire prepared by both researchers. The instrument of study covered (21) items, they had been distributed after assuring procedures of validity and reliability on a class on a random class sample, its component is (512) male and female students from the community of study amounting to (2592) during the second semester of the studying year (2017-2018). The most prominent results were that the teaching staff member's citizenship values came at a medium degree through the teaching process. Also, differences with statistical significance did not appear ascribed to both variables of sex (male \& female) and the faculty (human \& scientific). And in light of results, the researchers recommend the University Administration entrust the subject of citizenship greater importance and bid the professors to evaluate those values and enhance them in cultural and academic domains and activities, through the different plans of the studying subjects.
\end{abstract}

Keywords: citizenship values, Jordan Universities' Students

\section{Introduction}

In the shadow of what the world witnessed in the third millennium of different and acceleration changes in various social, scientific, cultural, and economic domains, the most prominent is the revolution of information technology and social communication sites. Today's world became more like a small village, which arranged the appearance of new patterns of behavior characterized by globalization, openness, and multi-cultures, showing customs and new traditions reflected on techniques of individuals and community's lives.

Those changes had accompanied the appearance of patterns of thinking, and new behavior was not previously known. They were spread and easily transferred by globalization, means and instruments of modern technology, and surely those changes and their effects on the states' social texture peoples, and individuals what the Arab region witnesses of worries and conflicts demand reviewing in its national oration with what escorts with the prevailing challenges. And in light of the Arab region's problem, it transforms the concept of citizenship into a pure slogan without a true translation of reality. The need became urgent to a national speech confessing and recognizing variety and considering it a positive value, and simultaneously seeks to work on achieving the social tenacity, therefore, reviewing the educational systems at the value of school and universities and look at the curriculums with the eye of the responsible desirous of protecting the national identity protecting it from (identity explosion) as called by (Howaida, 2017).

With globalization and the revolution of information technology, we have to accept the reality of dramatic changes that affect the techniques of life and methods of our thinking and commence with feeling and behavior as teachers to direct our students to differentiate among possibilities, ambition, benefits, and opportunities, challenges and dangers, and threats from another side.

This pushes us to develop the perception of freedom and responsibility incorrect choices- making, so as not to feel of negligence in the shadow of globalization. To consider humanitarianism and enhance the human connections and distribute their fruits and benefits at a just form (Lourdes, 2002), especially the goals of the university and its message is to build the personality of the student, develop his skills, release his possibilities, 
build the values of loyalty and belonging and bear the responsibility at students, to assist them in responding to requirements of life, serious work, and increase of productivity, enhance innovation and ability of invention, preparation of political, social, vocation and intellectual leaderships, effective and effecting their community (Mahmoud, 2014).

\section{What is citizenship}

Bilhasan (2015) confesses that citizenship is a concept that can be taught, learned, and trained. It works to strengthen and consolidate the individual's relations with his homeland and nation; it is learned through implanting values and concepts related to a group of rights and duties; the individual should represent them by practical application. It is the citizenship is not an inherited behavior, where the individual is not born provided with his citizenship, he acquires it as other learned behavior, of them are values and trends the modern citizenship is performed on citizenship, it works on overstepping the differences and ideological and intellectual belongings: political and cultural.

Al-A'wamerah and Al-Zoun (2014) defined citizenship that it is a sentimental behavioral expression at the individual reflects his love and loyalty to his homeland and nation; it is performed based on the individual's perception that he is an effective member of his community, has rights, and on him are duties. Meanwhile, Hiag (2016) talked about the development of citizenship and human rights in their present form and laid his imaginations about the citizen, nature of his rights and duties, and transition from the concept of the community of citizens into the community of countrymen who connect with philosophic and intellectual sides.

Jedouri (2014) indicated the significance of forming positive trends at students toward homeland love and protecting its security, unity, and necessity of soothsaying them with the important role that they should do toward what achieves the national unity, for the community to become more powerful and strong, and talked about the positive citizenship derived from higher human values, from them: freedom values, social justice, and effective participation to achieve man's dignity and cooperative work, the thing that allows developments to the communities. The Australian Ministry of Education (Department of Education) stressed the necessity of educating students for its role in teaching them cognitions, skills, and abilities that assist them in working with ethical fairness, pushing them to estimate the cultural and social variety.

In the developed countries, the United States of America is one of them, the philosophy of developing citizenship and enhancing its value is performed on adapting the American educational institutions at a great form and developing the self-concept of students and increasing the level of their trust in their abilities in creating the positive change. The USA to achieve that employs the policy of imposing education and law on all categories of the community, that shares in melting variation in the American community categories in accordance with legislations and American laws, meanwhile the modern Japanese system seeks to consolidate the values of the citizenship at generations through the political direction to support the values of the national loyalty for the political system, and consolidation of the group values that enriches the affair of the national belonging, and urge sacrifice with the personal benefit in return for the public interest and dedication of education to educate the individuals a type of the political culture generated at them and acquired most of them identical political trends so as there will never be a domain of performing sharp conflicts and disputes among them, the thing that paved the way to mobilize the different human resources for the economic development objectives and confront problems of the economic and social change, through concentrating the educational curriculums at them on a number of subjects that aim at developing the values of citizenship at generations, such as the ethical education that includes values of international cooperation, respect life and the need for assisting others. The national education at them lays a group of objectives they seek to achieve, the most important of which are: self-respect, others, and the whole humanity, understanding people, different cultures, and developing students' readiness to bear the responsibility toward themselves and their community, and increase of awareness of problems, local and international issues, and forming the trends concerning peace and international understanding, for the sake of that the Japanese government seeks to conclude a yearly conference in the domain of global education by the students' participation from different districts of Japan and activate them to prepare researches particularly concern traditions and Japanese values, human rights and contemporary problems in the Japanese community and interaction with the international experiences in the youth domain (A'seeri, 2015)

Al-Sharjah police Research Center (2017) defined citizenship as the legal relationship between the individual and the state; it is an outcome of the intellectual, political, religious, and social components.

Components of citizenship:

Al-Harbi and Sweilem (2017) divided citizenship into four parts; they are: 
Rights; mean the community's commitments toward its individuals of civil rights, equality rights, and human rights. Justice and obligations; mean an individual's commitments to systems and laws, defending the homeland and protecting it from any dangers. Belonging; that is the individual's belonging, and emergence in his community with what makes him feel of security and stability in a form guarantees giving up selfishness and self-centeredness in the path of values and trends of the social work loyalty. But the fourth part of citizenship is the societal participation; of effective volunteering and social works in the community's service.

\subsection{Problem of Study and Questions}

In the third millennium and the transformations that accompanied the age of globalization and the great openness of the world, the issue of citizenship and the role of universities in enhancing it remains in need of more research effort and study to activate values of citizenship and adopt studying and implanting them in youth souls by the academicians. Desiring originality of their values from one part, and fearing about their future from another part, especially with the increase of showing the guiding indicators on the contemporary value crisis and what we hear and witness of crime and misery transition and violation of human dignity, till became in some countries a painful phenomenon demands the hasty intervention and review the role of the educational incubators, especially universities for what they have of great influence on forming the personality of individuals, and exporting leadership and irritators. Therefore, the problem of the present study is specified in the following two questions:

1. What is the degree of a sample of students in Irbid National University estimation of the Teaching Staff Members' practice of teaching values connected with citizenship strategies?

2. Are there differences with statistical significance among means of estimation degrees by individuals of the sample for the Teaching staff Members of teaching strategies to values connect with citizenship ascribed to sex (male, female) and type of faculty (human, scientific)?

\subsection{Objectives of the Study}

- Recognition of the estimation by a sample of Irbid National University students to the Teaching staff Members practice of teaching strategies of teaching values connected with citizenship.

- Uncovering if there are differences with statistical significance among means of estimation degrees by individuals of the Teaching Staff Members' sample to practice strategies of teaching values connected with citizenship ascribed to variables of: (sex and type of the faculty).

\subsection{Significance of the Study}

The significance of this study comes from the nature of the problem it tackles. They are the strategies of citizenship values tackled by the Teaching Staff Member with his students in the university, especially with the increasing openness of communities, the Jordanian community, the world, and other different cultures. That is what is called globalization and what helped it in the world's advancement in information and communications, which caused the spread of social and cultural patterns hastily and efficiently. To protect values from overlap, intermixture, and the absence of cultural and civilized privacy. Educational institutions and universities must enhance these values, especially in the shadow of reflections of conflicts and wars in the region and exposure of human values to the danger of retreat and substitution of alien materialistic values in their place. Therefore, the significance of the study is specified in:

- This study is considered a response to numerous local and Arab symposiums and the previous studies to the necessity of universities to perform an effective role in educating citizenship.

- The significance of values connected with citizenship in youth's life, especially in the shadow of prevailing political inter attractions caused by the region's struggle and reflections.

- It is expected the following categories benefit from the study:

- The Teaching Staff Members provide them with their students' points of view about practicing strategies of teaching values connected with citizenship.

- University administration by informing it with the degree of the Teaching Staff Members practice of strategies to teach values connected with citizenship.

Education policymakers in public and Higher Education institutions to enhance and enrich the university determinants with the wished educational values, aiming to improve education quality by a philosophy that serves the community, where obtaining knowledge is not satisfactory. But how to attain knowledge and benefit from it in the practically applied domains and produce new knowledge, suit, and agree with the Twenty-First Century skills. 
- The educational, youthful, social and cultural institutions in the community, in a form guaranteeing forming concepts of citizenship, human rights, creating man, the citizen belonging full of love to his homeland, aware of his rights and duties, open on the external world in a tolerant form, accepting the change, defending his humanitarianism and right of the world to live in peace.

It can also benefit students themselves from its results in challenging abundant cultural variables for barriers between them and social adaptation and elasticity in dealing.

\subsection{Study Determinants}

- Subject determinant: recognizing the degree of the Teaching Staff Members in university practice of strategies to teaching values connected with citizenship from the students' perspective.

- Place determinant: Irbid National University (one of the North Universities), Irbid governorate in the North of the Hashemite Kingdom of Jordan.

- Human determinant: a sample of male and female students registered for the second semester of 2016/2017.

- Time determinant: the field study was done in the second semester of the studying year 2016/2017.

\subsection{Terminology of Study}

1. Citizenship: Jidouri (2004) defines it that it is: a concept that can be learned and trained, it works on strengthening tightening the individual's relationship with his country and homeland, he is being taught through implanting values and the concepts related with a group of rights and duties that the individual should resemble by the practical application.

Both researchers procedurally define it: that it is a group of activities or behavior frames performed by the Teaching Staff Member of direction and educational counseling to his students, through lectures, symposiums, conferences, and meetings, either inside the university or outside of it, for the sake of developing values, and they are measured by the estimated degree on the instruments of study.

\section{The Teaching Staff Member:}

Both researchers procedurally define him: he who works in teaching from the professors, assistant professors, and the full-time and part-time associate professors in Irbid National University, and they are expected to perform a role in developing values connected with citizenship at their students.

1. Values: they are linguistically defined that they are plural of the word "value," and it is the thing with the amount. And it is idiomatically defined that it is a group of ethical attributes, by which humans are distinguished, and the social life is performed on it. And it is being expressed by employing sayings and actions.

2. Values of Citizenship: values of citizenship are practiced as a culture, and a civilized behavior performed based on cooperation and participation by all individuals of the homeland in the shadow of equality and social justice and sovereignty of the law, and these values are distinguished with reliability, stability, and non-pliability for change to an extent for their connection with the culture of the community and its permanents (Al- A'bboud, 2011).

Both researchers define values connected with citizenship: a group of items included in the instrument of study (questionnaire) through which the Teaching Staff Members are governed on the extent they resembled through their teaching the different academic determinants.

\section{Previous Studies}

Al- Harbi and Swielem (2017) prepared a study entitled: "Developing Citizenship at Saudi Universities' Students."

It aimed at clearing the theoretical frames of citizenship issue and machinery of their development at Jizan students. Both researchers employed the instruments of study, prepared by them both, consisted of (31) items to measures points of view of students in the university in what relates with variables of the study and their relation with domains of citizenship, they are: the cultural, social, physical, dramatic, innovative, and scout activities. The study instrument was applied to a sample of university students; their number amounted to (305) students. Results showed students' agreement to a great degree on sharing the cultural and social activity in developing citizenship at them.

A'dly (2017) talked in her published article entitled "value of citizenship at Arab Universities" about the significance of teaching citizenship at schools and universities. 
She mentioned the most important problems and crises that confront the Arab region and their effect on the national education and work on their transformation into hollow slogans without true translation on reality, and the identity explosion (as she called it) in the region is nothing. Still, it is a natural consequence of the problem of citizenship. She caught the attention to what the Arab region witness of struggles and worries require reviewing its address about citizenship, and restore balance to it with what escorts with prevailing challenges; also the need became urgent to an address sets out of confirming the variety and considering it a positive value and work to achieve the social solidity.

To investigate the university's role in developing values of citizenship and its resemblance to students, Ali (2017) did a field study on a sample of (1065) male and female students from both universities, Asyout and Sahaj. The study aimed to recognize the university's role in developing values of citizenship and reconnoitering the degree of those values' resemblance at its students and their awareness of the effect of globalization challenges in the concept and dimensions of citizenship. To achieve that, both researchers prepared a questionnaire consisted of (79) items. They both applied it to the sample of the study. Results of the study deduced that the university shares a great degree in developing the values of citizenship. Differences with significance did not appear in the degree of citizenship values resemblance ascribed to sex (male, female) and the faculty type (human, scientific).

In a study aimed at submitting a proposed imagination to develop citizenship values in curriculums of sciences at students of public education in the Kingdom of Saudi Arabia. Al- Harbi (2016) submitted a list of axes and subsidiary items as a proposed imagination to develop the value of citizenship employing the Delphi Technique on a sample of (30) of the Teaching Staff Members at three Saudi universities covering a group of different specializations.

The study's results deduced to building a proposed imagination to develop citizenship values in curriculums of sciences at students of public education, consisting of five main axes, they are programs of preparing teachers, studying curriculums, evaluation techniques, school activities, and programs of community service.

In (Ghafer, Al- S'aeedi, and Al-Hamidi, 2015) study, the researchers aimed at investigating the educational supervisors' point of view in uncovering the degree of Islamic Education teachers and social studies practice the citizenship values in the summer interaction, in addition to recognizing the effect of both variables: the type (male and female) and specialization. To achieve the study's purpose, researchers employed the descriptive method and depended on a questionnaire consisting of (30) items that had been applied to the sample of the study consisted of (75) male and female supervisors. The study results showed that the degree of Islamic Education Teachers and social studies practiced citizenship values and came medium in the total of questionnaire items. Also showed inexistence of differences with statistical significance between male and female supervisors ascribed to the variable of type (male, female) and the variable of specialization, and the researchers recommended the necessity of carrying out workshops and training programs for teachers on teaching values of citizenship by employing methods and techniques of modern teaching. The study also submitted a group of propositions for future studies: studying difficulties that confront teachers in employing values of citizenship in education.

Abdel Razeg (2011) did a comparative study in both universities: Damascus and Tehran entitled "Role of the university in Developing the Social Relations and the National Responsibility" to obtain the master degree from the Faculty of Education in Damascus University. She found from the results of a study that youths' owning the culture of citizenship with its values and concepts is considered the system of immunity in the community's body by achieving the national interaction and mutual human coexistence, understanding among individuals of the one homeland. Both researchers submitted recommendations to enhance the university role in developing the national responsibility, the most important of which are: directing students to do researchers related to the subject of citizenship and enhancing it, students' participation in the volunteering campaigns organized by the university in an effective form, counseling students to the necessity of accepting others, non- fanaticism, specification of a time for dialogue and discussion in the national and political issues, activating the field visits and volunteering campaigns for the community service, and connecting the issues tackled by the curriculum, with the national issues.

And in a study entitled "Role of the Jordanian Universities in Supporting Values of Citizenship" done by both researchers: Al- I'geil and Al-Hiyari (2004) on a sample consisted of (371) Members of the Teaching Staff at the scientific faculties and humanities in the Jordanian Universities; they were chosen by the random class method. Both researchers employed a questionnaire covered (29) items. Results of the study showed that the most prominent citizenship values sought to be consolidated by universities are loyalty and belonging, love of homeland, and desire for security and stability. And in light of those results of their study, both researchers 
recommended the necessity of Jordanian Universities' adoption, in their educational philosophy, of citizenship values, and activating them scientifically and theoretically, and let universities have a role in activating the system of inquiry, control to annihilate corruption inside universities and implement laws and systems to exterminate favoritism and intermediary.

Al-A'wamirah and Al-Zioun (2014) study about the faculty of educational science students' point of view on the role of the formal Jordanian Universities in enhancing the citizenship values and their relation with developing self-independence at a class- random sample consisted of (680) male and female students from the origin of the community of study, amounting to (6929) individuals in the studying year (2011/2012). Both researchers employed the study instrument consisting of a questionnaire covering (55) items, (15) items that measure self-independence. The study deduced the great role of the universities in axes of rights, duties, and justice. The study recommended universities to adopt a comprehensive national strategy for the national education shares in enhancing understanding and perception of students to its axes.

(Al-Khawaldeh, 2013) the study aimed at recognizing the level of the Teaching Staff Members role in the Jordanian universities in developing citizenship values from the students' point of view, and recognizing the differences in the level of the role due to variables of sex, the university, the faculty and level of study. To achieve the study's objectives, both researchers did prepare a questionnaire that included (48) items, distributed on the sample of the study, amounting to (928) and chosen by the class-random method from the community of study. Their study showed that the Teaching Staff Members' role in teaching values from the students' point of view at a medium degree in general form, and in all domains.

The results also showed the existence of differences with statistical significance ascribed to variables of the student gender (male or female) for the interest of males and variable of the university, for the interest of private universities, and the faculty's variable for the interest of faculties of humanity. As for the variable of study level, for the interest of first-year students, and in light of study results, both researchers had recommended with the necessity of the university administration to entrust the subject of citizenship values abundant care and bid the Teaching Staff Members concentrate on these values and enhance them in students' souls, and include them in the studying determinants.

\section{The Methodology of the Study}

To achieve the objectives of the study, both researchers did employ " the descriptive-analytical method," it is a method that studies a phenomenon, or an issue that exists now can attain information answer the questions of study without the intervention of the researcher in it, that attempts through it to describe the phenomenon, the subject of study:

(The Teaching Staff Members degree of employment of teaching citizenship values strategies from Irbid National University Students' point of view).

Analyzing its data and clarifying the relationship between its components and opinions raised about it and operations it included and the effects it causes. It is one of the analysis forms and organized scientific explanation to describe a phenomenon, or a specified problem and imagine it in quantity by the method of collecting data and lawful information on about the phenomenon, or the problem and classifying it, analyzing, and subdue it for the accurate studies (A'ssaf, 2017).

\subsection{Instrument of Study}

After informing on the educational literature and the previous studies related to the problem of study and exploring the opening of a sample of specialists by the method of personal meetings with informal nature, both researchers did organize the questionnaire by the following steps:

- Items wording.

- Preparing the questionnaire in its initial form that covered (26) items.

- Showing the questionnaire to (6) members of the Teaching Staff specialist in education and psychology in Irbid National University and the surrounding universities: Yarmouk University and Jadara University.

- Arbitrators' notices had been taken from part of amending the linguistic wording, or amending several items, or omitting some of them, and after doing the required amendments, the questionnaire was stabled at its final form on (21) items.

\subsubsection{Reliability of Study Instrument}

To be assured of the study instrument's reliability, it had been recognized by the method of test and retest by 
applying the questionnaire and replying it after two weeks on a group from outside the sample of the study, consisting of (15) male and female students. So person connection coefficient had been counted among their estimations in both cases. The reliability coefficient was also counted by the method of internal consistency due to Cronbach Alpha Equation amounted (0.88). Reliability of the instrument's return as a whole amounted to (0.90); these values were considered suitable for this study.

\subsection{Statistical Standard}

The fivefold Likert Scale to correct instruments of the study had been confirmed, by giving each item of its items one degree from its five degrees (Very high, high, medium, low, very low) it represents in number $(5,4,3,2,1$, consecutively. The following scale had been confirmed for purposes of analyzing results:

$\begin{array}{lll}\text { From } & 1.00-2.33 & \text { low } \\ \text { From } & 2.34-3.67, & \text { medium } \\ \text { From } & 3.68-5.00 & \text { high }\end{array}$

And so on

And the scale had been counted through employing the following equation:

The highest limit of the scale (5) - the lowest limit of the scale (1)

Number of required classes (3)

$\underline{5-1}=1.33$

3

And then add the answer (1.33) to the end of each class.

\subsection{Sample of Study}

Table 1. Repetitions and percentages due to variables of the study

\begin{tabular}{cccc}
\hline Variables & Classes & Repetition & Percent \\
\hline \multirow{2}{*}{ Sex } & Male & 207 & 40.4 \\
& Female & 305 & 59.6 \\
\multirow{2}{*}{ Specialization } & Scientific & 124 & 24.2 \\
& Human & 388 & 75.8 \\
& Total & 512 & 100.0 \\
\hline
\end{tabular}

\section{Results of Study}

The first question: What is the degree of estimating a sample of Irbid National University Students of the Teaching Staff Members practice teaching values strategies connected with citizenship?

To answer this question, the arithmetic means and standard deviations were extracted to estimate a sample of students from Irbid National University to the Teaching Staff Members in it of strategies of teaching values connected with citizenship. The below- mentioned table clears that:

Table 2. The arithmetic means and standard deviations of the degree of estimating a sample of Irbid National University Students for the Teaching Staff Members in it practice strategies of teaching values connected with citizenship descending organized due to arithmetic means

\begin{tabular}{|c|c|c|c|c|c|}
\hline Rank & No. & Items & $\begin{array}{l}\text { Arithmetic } \\
\text { Mean }\end{array}$ & $\begin{array}{l}\text { Standard } \\
\text { Deviation }\end{array}$ & Degree \\
\hline 1 & 1 & $\begin{array}{l}\text { What issues from students of statements connected with } \\
\text { traditions of community to clarity values are invested }\end{array}$ & 3.93 & 1.016 & High \\
\hline 2 & 20 & $\begin{array}{l}\text { It constantly asked about the extent of criticism accuracy or } \\
\text { difference in opinion }\end{array}$ & 3.80 & 1.197 & High \\
\hline Rank & No. & Items & $\begin{array}{l}\text { Arithmetic } \\
\text { Mean }\end{array}$ & $\begin{array}{l}\text { Standard } \\
\text { Deviation }\end{array}$ & Degree \\
\hline 3 & 10 & $\begin{array}{l}\text { It is asked about practical steps followed by students to apply } \\
\text { their value satisfactions }\end{array}$ & 3.74 & 1.185 & High \\
\hline 4 & 8 & $\begin{array}{l}\text { It is cleared to students that belonging to the homeland is the } \\
\text { scale of good citizenship }\end{array}$ & 3.70 & 1.099 & High \\
\hline
\end{tabular}




\begin{tabular}{|c|c|c|c|c|c|}
\hline 5 & 21 & Support the spirit of consolidation with the national issues & 3.70 & 1.259 & High \\
\hline 6 & 3 & $\begin{array}{l}\text { Questions are directed to assist students in discovering their } \\
\text { attitudes toward the homeland }\end{array}$ & 3.62 & 1.132 & Medium \\
\hline 7 & 15 & $\begin{array}{l}\text { Develops the ability of students on evaluating values of } \\
\text { belonging and citizenship }\end{array}$ & 3.55 & 1.301 & Medium \\
\hline 8 & 19 & Allows students to participate in the process of decision-making & 3.49 & 1.259 & Medium \\
\hline 9 & 14 & $\begin{array}{l}\text { Depends on mental skills in making students review their } \\
\text { concepts about rights and obligations }\end{array}$ & 3.40 & 1.307 & Medium \\
\hline 10 & 7 & Clears consequent result on equalizing all in front of the law & 3.37 & 1.311 & Medium \\
\hline 11 & 5 & $\begin{array}{l}\text { Asserting the principle of working by an appropriate choice of } \\
\text { national symbols }\end{array}$ & 3.36 & 1.174 & Medium \\
\hline 12 & 9 & Shows estimation of students' responses and their point of view & 3.35 & 1.241 & Medium \\
\hline 13 & 11 & Leaves domain for students to recognize their national identity & 3.35 & 1.206 & Medium \\
\hline 14 & 17 & $\begin{array}{l}\text { Students participate in activities connected with national } \\
\text { occasions }\end{array}$ & 3.33 & 1.163 & Medium \\
\hline 15 & 6 & Constantly ask about what good citizenship values mean & 3.28 & 1.252 & Medium \\
\hline 16 & 2 & $\begin{array}{l}\text { Employs the feeling of students for belonging in clearing value } \\
\text { of preserving properties of the homeland }\end{array}$ & 3.20 & 1.166 & Medium \\
\hline 17 & 18 & $\begin{array}{l}\text { Discussion is directed to reach the student to issue value verdicts } \\
\text { about their obligations toward the homeland }\end{array}$ & 2.94 & 1.177 & Medium \\
\hline 18 & 4 & $\begin{array}{l}\text { Students are recognized with dangers that threaten the security } \\
\text { of the homeland as a result of getting out rationality }\end{array}$ & 2.82 & 1.073 & Medium \\
\hline 19 & 12 & $\begin{array}{l}\text { Assists the students constantly in specifying the value issue with } \\
\text { a national dimension }\end{array}$ & 2.54 & 0.968 & Medium \\
\hline 20 & 13 & Concerns with showing the frank or the implied forms & 2.50 & 1.016 & Medium \\
\hline \multirow{3}{*}{21} & \multirow{3}{*}{16} & For commitment to citizenship & & & \\
\hline & & $\begin{array}{l}\text { Differential statements are employed to consult students' ideas } \\
\text { and direct their value verdicts }\end{array}$ & 2.11 & 563 & Low \\
\hline & & Total Degree & 3.29 & 0.689 & Medium \\
\hline
\end{tabular}

Table (2) clears that arithmetic means had amounted between $(2.11-3.93)$, where the item No. (1) that words "what issues from students of expressions connected with traditions of the community to clear values" came in the first rank and with arithmetic mean amounted (3.93). Meanwhile, item No. (16), words "it employs differential statements to excite students' ideas and direct value verdicts" in the last rank and arithmetic mean (2.11), and the arithmetic mean of the instrument as a whole (3.29). Perhaps the cause in that refers to teachers' approach from their students, especially a cultural and one social background gathers them, but about the item occupying the last rank "employs differential statements to excite students' ideas and direct their value verdicts'. Perhaps the cause in that refers to teachers' preoccupation in exacting their studying plans, and their desire not to waste the time of the lecture, for their belief is that dialogue and discussion outside the subject of lectures are unnecessary or may get the discussion out of its limits to allow getting out or appearance of unacceptable differential ideas, lead to lead conflicts happening.

Second question:

Are there differences with statistical significance among means of estimations of the sample of study individuals for the Teaching Staff Members practice of teaching strategies of values connected with citizenship due to both faculty and sex variables?

Table 3. Means and standard deviations according to the variables

\begin{tabular}{ccccc}
\hline Variable & Classes & Arithmetic Mean & Standard Deviation & No. \\
\hline \multirow{2}{*}{ Sex } & Male & 3.64 & 0.549 & 207 \\
& Female & 3.05 & 0.672 & 305 \\
\multirow{3}{*}{ Specialization } & Scientific & 3.26 & 0.704 & 124 \\
& Human & 3.30 & 0.685 & 388 \\
& Total & 3.29 & 0.689 & 512 \\
\hline
\end{tabular}


Table 3 clears apparent variation in the arithmetic means and standard deviations to the degree of estimating a sample of Irbid National University Students to practice strategies of teaching the values connected with citizenship, because of difference at classes of both variables of sex (male, female) and type of the faculty (human and scientific). To clarify the significance of statistical differences among the arithmetic means, analysis of double variation had been used, Table 4.

Table 4. Analysis of double variation of the effect of sex and type of the faculty on the degree of estimating students of Irbid National University for the Teaching Staff Members practice of the strategies of teaching the values connected with citizenship

\begin{tabular}{cccccc}
\hline Source of Variation & Total of Squares & Degrees of Freedom & Average of Squares & F. Value & Statistical significance \\
\hline Sex & 45.241 & 1 & 45.241 & 116.704 & .000 \\
Specialization & 2.170 & 1 & 2.170 & 5.599 & .018 \\
Error & 197.317 & 509 & .388 & & \\
Total & 242.738 & 511 & & & \\
\hline
\end{tabular}

It is clear from the Table 4 the following:

Existence of differences with statistical significance $(a=0.05)$ ascribed to the effect of sex, where the F. value amounted to 116.704 with statistical significance amounted to 0.000 , and the differences were for the interest of males, perhaps the cause of that is the increase of students' desire to sharing in the national occasions and opening the door of dialogue in those domains with their teachers.

The existence of differences with statistical significance $(a=0.05)$ ascribed to the effect of specialization, where the F. value amounted to 5.599 with statistical significance amounted to 0.018 . The differences came from the interest of specializations of humanities, and the cause of that, students of the university from humanities specializations may be more preoccupied in the national and cultural activities, and less exploiting time of the study, the thing that makes the factor of additional time at them available.

\section{Recommendations}

Both researchers hope that this study shares in developing and enhancing values of citizenship and its resemblance at students and teachers, in the form that increases the level of awareness and the national perception at them, desiring the solidity of the community and turning away the dangers that may catch it.

Both researchers recommended the necessity of concluding periodical meetings between the university students and instructors, in which research and discussing several important national issues are done and discussing methods of treating them in an appropriate educational atmosphere.

Both researchers also recommend including the national education subject a group of values and high ideals that work on increasing the participation of students and teachers in bearing the national concern and perception of cooperation importance and interaction to support issues of the community and methods of treating them.

- The necessity of specifying a part of symposiums and lectures at the level of the university to discuss and tackle the national issues, including the social and political ones.

- Organizing field visits to the students accompanied by their teachers to the administrative and upper political parts in the country, such as the people's council (the parliament) and the different controlling parts, informs the machinery of decision-making transparently.

- Supporting youth initiatives with value in the service of the community and the social work of volunteering.

\section{References}

A Researcher Submitted in the First Conference of the Faculty of Education in Palestine University values in the Palestinian Community: A Reality and Challenges.

A'dli, H. (2017). Value of Citizenship at the Arab Universities. Journal of Additions, 36-37.

AbdelRazzag, L. (2014). Role of the University in Developing the Social Relations and the National Responsibility (A Field Study in Both Universities: Damascus and Tishreen). Master Degree Dissertation. Damascus University, Faculty of Education.

Al A'bboud, A. (2011). Values of Citizenship at youths and its Sharing in Enhancing the Preventive Security. Nayef Arab University for Security Sciences - Riyadh.

Al- A'geel, I'smat and Al-Hiyri, Hassam, (2014). 
Al- Hussein, B. (2015). Desired Citizenship and Development. Journal of Developing Resources.

Al-A'awamerah, A., \& Al-Zyoun, M. (2014). Role of Formal Jordanian Universities in Enhancing Education of Citizenship and its Relationship With Developing the Self- Independence at Students of the Faculty of Educational Sciences from their perspective. Journal of Al-Najah University for Research (Humanities), 28(1), 187-218.

Al-Gafer, H., Al-Saeedi, H., \& Al-Hamidi, M. (2015). Degree of Islamic Education Teachers and Social Studies Practice of Citizenship Values in the Class Interaction from the Point of View of Educational Supervisors in Oman Sultanate. Journal of Developing Human Resources, 11.

Al-Harbi, A. (2016). Proposed Imagination for Developing Values of Citizenship in the Curriculums of Sciences at Students of Public Education in the Saudi Arab kingdom. Journal of the Faculty of Basic Education of Educational Sciences and Humanities, (27).

Al-Harbi, Q., \& Seilem, M. (2017). Developing Citizenship at Saudi Universities Students (Jezan University a Model). Journal of the Faculty of Education Al-Azhar University, (176).

A'ssaf, M. (2017). The degree of teaching staff in the Palestinian Universities practice of teaching values connected with Citizenship and Methods of Enhancing it.

A'sseri, A. (2015). Arab and Universal Experiments to Enhance Values of Citizenship. Enhancing Symposium of Citizenship Values, and its Role in Fighting Terrorism. Imam Mohammad Bin Saud Islamic UniversityRiyadh.

Australian Government Department of Education Work Place Relations. (2010).

Civics and Citizenship Education.

Hamdi, A. (2017). Role of the University in Developing Values of Citizenship and its Resemblance at Students in the Shadow of Globalization Challenges: A Field Study of a Sample from Students of Both Universities: Asyout and Sohaj. Sharijah University Journal for Humanities and Social Sciences, 14(1).

Hiyag, I. (2016). Citizenship and Human Rights in Light of the Last Educational Reforms in Algeria. Doctorate Dissertation.

Hussein, M. (2014) Causes of University Violence and its Forms from a Sample of University Students' point of view. Journal of Al-Aqsa University (Series of Humanities), 18(1).

Jedouri, S. (2004). Developing Universal Citizenship Values at University Students Stage. Researches and Studies of Damascus University.

Jedouri, S. (2014). significance of enhancing dialogue at the university environment from the Teaching Staff Members Point of View in Tiebah University. Journal of Educational and Psychological Sciences, (3), 15. https://doi.org/10.12785/jeps/150312

Khawaldeh, T. (2013). Role of Teaching Staff Members in the Jordanian Universities in Developing Values of Citizenship from the Students' Point of View. Studies of the Educational Sciences, 40(3).

Lourdes, R.(2002). Citizenship Education for Better World Societies: A Holistic Approach paper read at the 8th UNESCO APEID International Conference on Education, Bangkok.

Role of the Jordanian Universities in Supporting Values of citizenship. The Jordanian Journal in the Educational Sciences, 10(4), 529-517.

Sharjah Police Researches Center- United Arab Emirates. (2017). Enhancing Values of Citizenship and Their Role in Generations Fortification from Deviation with States of Cooperation Council.

Thbeiti, M. (2016). Role of the University Administration in Developing Values of Citizenship at Tabouk University Students. Teebah Journal for Educational Science, 11(3), 349-365.

\section{Copyrights}

Copyright for this article is retained by the author(s), with first publication rights granted to the journal.

This is an open-access article distributed under the terms and conditions of the Creative Commons Attribution license (http://creativecommons.org/licenses/by/4.0/). 